\title{
CEGAH AMPUTASI GANGRENE PENDERITA DIABETES MELLITUS TIPE 2 MELALUI PEMANFAATAN MEDIA VIDEO SENAM KAKI
}

\author{
Dwi Novitasari ${ }^{1^{*}}$, Prasanti Adriani ${ }^{2}$, Tyas Amalia Khaerunisa $^{3}$, Sidik Awaludin $^{4}$ \\ 1-3Universitas Harapan Bangsa \\ ${ }^{4}$ Universitas Jenderal Soedirman \\ "Email Korespondensi: dwinovitasari@uhb.ac.d
}

Disubmit: 05 Juli 2021

Diterima: 08 Juli 2021

DOI: https://doi.org/10.33024/jkpm.v5i2.4623

Diterbitkan: 01 Februari 2022

ABSTRAK

Diabetes mellitus (DM) menjadi masalah kesehatan di seluruh dunia, diperkirakan 462 juta orang $(6,28 \%$ populasi dunia) terkena DMT2. Hiperglikemia kronik menyebabkan disfungsi endotel seperti kalsifikasi medial arteri yang menyebabkan gangguan sirkulasi dan syaraf di kaki. Ulkus DM yang terinfeksi menyebabkan gangrene sehingga berisiko amputasi apabila tidak ditangani. Ankle Brachial Index ( $\mathrm{ABI}$ ) untuk screening gangguan sirkulasi kaki. Strategi pencegahan mengurangi risiko ulkus, gangrene dan amputasi dapat menggunakan pendidikan kesehatan pada pasien terkait gaya hidup dan olah raga/senam. Angka kejadian DM tertinggi di Desa Karanggedang dibandingkan 10 desa lainnya di Kecamatan Sidareja. Sejumlah 61 orang DMT2 memiliki GDS > $200 \mathrm{mg} / \mathrm{dl}$. Tujuan PKM ini yaitu meningkatkan kesadaran penderita DMT2 tentang gaya hidup yang baik, serta perbaikan sirkulasi perifer dengan perbaikan nilai $A B I$ pada 2 kali pengkuran. Metode PKM ini menggunakan ceramah, diskusi, tanya jawab, wawancara, demonstrasi, redemonstrasi, dan menonton video senam kaki diabetes meliputi tahap persiapan hingga evaluasi sebanyak 14 kali pertemuan. Didapatkan hasil rata-rata peserta berumur 55,27 tahun, mayoritas memiliki hipertensi $9(60 \%)$ orang, lama menderita DM 1-6 tahun, skala nyeri pre 5 (sedang) yang menurun 2 poin menjadi 3 (ringan), mengeluh baal pre $12(80 \%)$ dan membaik menjadi $5(33,5 \%)$ orang, kadar GDS pre $216,07 \mathrm{mg} / \mathrm{dl}$ menurun menjadi $185 \mathrm{mmg} / \mathrm{dl}$, nilai $\mathrm{ABI}$ pre seluruh peserta 0,81 (abnormal) dan membaik seluruhnya saat post 1,12 (normal) yang signifikan secara statistik. Saran bagi penderita DMT2 di Desa Karanggedang agar tetap rutin melakukan senam kaki diabetes secara mandiri, dan bagi kader kesehatan aktif mengingatkan dan memotivasi penderita untuk melakukan senam kaki diabetes secara rutin.

Kata kunci: senam kaki diabetes, $\mathrm{ABI}$, gangren, amputasi.

\begin{abstract}
Diabetes mellitus (DM) is a health problem worldwide, it is estimated that 462 million people (6.28\% of the world's population) are affected by T2DM. Chronic hyperglycemia causes endothelial dysfunction such as calcification of the medial artery which causes circulatory and nerve disorders in the legs. Infected DM ulcers cause gangrene so that there is a risk of amputation if untreated. Ankle
\end{abstract}


Brachial Index $(A B I)$ is used to screen for circulatory disorders in the legs. Prevention strategies to reduce the risk of ulcers, gangrene, and amputation can use health education in patients related to lifestyle and exercise/sports. The highest DM incidence was found in Karanggedang Village compared to 10 other villages in Sidareja District. A total of 61 DMT2 patients had GDS > $200 \mathrm{mg} / \mathrm{dl}$. The purpose of this community service is to increase awareness of DMT2 sufferers about a good lifestyle, as well as to improve peripheral circulation by increasing the $A B I$ value in 2 measurements. This community service method uses lectures, discussions, questions and answers, interviews, demonstrations, re-demonstrations, and watching videos of diabetic foot exercises starting from the preparation stage to evaluation for 14 meetings. The results showed that the average age of participants was 55.27 years, have hypertension 9 (60\%) people, have suffered for 1-6 years, pre pain scale 5 (moderate) decreased by 2 points at the post becomes 3 (mild), pre numbness complaints 12 (80\%) and improved to 5 (33.5\%) people, pre levels blood glucose $216.07 \mathrm{mg} / \mathrm{dl}$ which decreased post levels blood glucose becomes $185 \mathrm{mg} / \mathrm{dl}$, the pre-ABI of all participants was 0.81 (abnormal) and a statistically significant increase at all at post 1.12 (normal). Suggestions for DMT2 sufferers in Karanggedang Village to continue to regularly do diabetes foot exercises independently, and for care providers to always actively remind and motivate the sufferers to routinely do diabetic foot exercises.

Key words: diabetic foot exercise, $A B I$, gangrene, amputation.

\section{PENDAHULUAN}

Diabetes mellitus (DM) menjadi perhatian utama dalam perawatan kesehatan di seluruh dunia. Secara global, diperkirakan 462 juta orang terkena diabetes mellitus tipe 2 (DMT2), setara dengan 6,28\% dari populasi dunia. Lebih dari 1 juta kematian dikaitkan dengan DMT2 pada tahun 2017 saja, menempatkannya sebagai penyebab utama kematian kesembilan. Peningkatan mengkhawatirkan jika dibandingkan dengan tahun 1990, ketika DM menduduki peringkat ke delapan belas penyebab utama kematian, dan terkait penyakit yang menyengsarakan DM menempati urutan ke tujuh dari berbagai penyakit. Data pada tahun 2017, sekitar 462 juta orang terkena DMT2 sesuai dengan 6,28\% dari populasi dunia (4,4\% berusia $15-49$ tahun, $15 \%$ berusia $50-69$, dan $22 \%$ berusia $>70$ tahun), puncak insiden pada usia sekitar 55 tahun. Prevalensi global DMT2 diproyeksikan meningkat menjadi 7.079 orang per 100.000 pada tahun 2030, mencerminkan peningkatan yang berkelanjutan di semua wilayah di dunia. Ada tren peningkatan prevalensi yang mengkhawatirkan di negara-negara berpenghasilan rendah (Khan et al., 2020).

Data Riskesdas 2018 prevalensi diabetes mellitus pada tahun 2017 sebanyak $1,2 \%$, sedangkan pada tahun 2018 mengalami peningkatan menjadi 2,6\% dengan karakteristik yaitu dialami pada penduduk kelompok umur 55-64 tahun, jenis kelamin perempuan, pendidikan tidak tamat SD/MI, pekerjaan PNS / TNI / Polri / BUMN / BUMD sebanyak (4,2\%) dan pada tempat tinggal di perkotaan (Dep. Kes RI, 2018). Diabetes melitus merupakan kumpulan gejala akibat meningkatnya kadar glukosa darah (hiperglikemia) yang disebabkan kekurangan insulin baik absolut maupun relatif (American Diabetes Association, 2020). Kondisi hiperglikemia disebabkan oleh tiga faktor utama yaitu 1) adanya gangguan pada pankreas, dapat berupa penurunan 
sensitivitas terhadap kadar glukosa darah dan/atau sekresi insulin yang abnormal, 2) adanya peningkatan glukosa produk hati karena peningkatan glukoneogenesis, 3) stimulasi glukagon dan katekolamin serta adanya resistensi insulin pada jaringan perifer yang berakibat gangguan transportasi dan metabolisme glukosa. Diabetes mempengaruhi kapasitas fungsional individu dan kualitas hidup, menyebabkan morbiditas yang signifikan dan kematian dini. Peningkatan konsumsi makanan yang tidak sehat dan gaya hidup yang tidak aktif, mengakibatkan peningkatan Indeks Massa Tubuh (IMT) dan glukosa plasma puasa (Gupta et al., 2020).

Hiperglikemia kronik menyebabkan disfungsi endotel melalui berbagai mekanisme, seperti: 1) menyebabkan glikosilasi protein sehingga terjadi perubahan tekanan intravaskular dan mengganggu reaktivitas serebrovaskular karena ketidakseimbangan Nitrite Oxside (NO) dan prostaglandin. 2) Meningkatkan aktivasi Protein Kinase C (PKC) intraseluler yang akan menghambat produksi NO. 3) Hiperglikemia akan meningkatkan sintesis diacylglycerol (DAG) berefek pada vasokonstriksi. 4) Menyebabkan kecenderungan stres oksidatif dan meningkatkan jumlah lipoprotein teroksidasi, terutama LDL kolesterol kecil (LDL teroksidasi) yang lebih aterogenik. 5) Peningkatan prothrombosis dan agregasi trombosit (Dietrich et al., 2017). Disfungsi endotel bermanifestasi pada proliferasi sel endotel, penebalan membran basal, pada dasarnya menyebabkan penyakit mikrovaskuler yang bertanggung jawab untuk iskemia. Hiperglikemia juga dikaitkan dengan peningkatan tromboksan A2 yang menyebabkan hiperkoagulabilitas plasma (Braiki et al., 2020). Disfungsi endothel menyebabkan sirkulasi darah ke kaki terhambat mengakibatkan kerusakan saraf dan struktur lainnya di kaki. Kondisi awal neuropati ditandai dengan keluhan kesemutan, lemah, mati rasa, dan nyeri di kaki (Rachek, 2014).

Peripheral arterial disease (PAD) adalah manifestasi aterosklerosis merupakan penyakit pembuluh darah aterosklerotik yang sering ditemukan pada pasien diabetes. Prevalensinya berkisar antara 9,5\% dan 13,6\% 36,37 pada pasien DMT2, 4\% pada populasi umum. Setiap peningkatan $1 \%$ kadar hemoglobin terglikosilasi (HbA1c) maka meningkatkan 28\% risiko PAD berdasar Studi Diabetes Prospektif di Inggris (UKPDS). Gangguan sirkulasi ke kaki karena PAD dapat menyebabkan penyakit kaki diabetik sehingga menurunkan kualitas hidup pasien dan memengaruhi partisipasi sosial. Ini termasuk beberapa komplikasi kronis seperti infeksi, ulserasi kaki dan bahkan kerusakan jaringan kaki. Komplikasi ini dianggap sebagai penyebab morbiditas dan mortalitas yang signifikan pada pasien DM. Faktor etiologi utama penyakit kaki penderita DM adalah kerusakan saraf perifer dan penyakit pembuluh darah perifer. Serangkaian mekanisme didokumentasikan seperti penurunan aliran darah perifer dan penurunan angiogenesis lokal. Penyakit kaki penderita DM dapat berupa ulkus dengan komplikasi infeksi bakteri menyebabkan gangrene. Gangrene menyebabkan risiko amputasi yang tinggi pada penderita DM apabila tidak ditangani dengan baik (Braiki et al., 2020).

Ankle Brachial Index ( $\mathrm{ABI})$ merupakan metode sederhana untuk screening PAD dan untuk mengevaluasi prognosis kardiovaskular (CV) pada populasi umum. Nilai $A B I$ pada pasien diabetes sering meningkat karena kalsifikasi medial arteri. Nilai ambang $A B I<0,9$ dan $>1,4$ berisiko tinggi $P A D$ dan penyakit CV pada pasien diabetes. American Diabetes Association merekomendasikan pengukuran $A B I$ pada semua pasien $D M$ yang berusia lebih dari 50 tahun (AlGhatrif et al., 2017). Tekanan yang lebih tinggi dari kedua 
pergelangan kaki dibagi oleh tekanan arteri brakialis. Pada subjek dengan sirkulasi arteri tungkai bawah normal, tekanan sistolik di pergelangan kaki biasanya 10-15 mmHg lebih tinggi daripada yang tercatat dari lengan karena kecepatan gelombang nadi, menghasilkan $A B I>1,10$. Perhimpunan medis internasional besar merekomendasikan penghitungan $A B I$ dengan membagi tekanan tertinggi di tungkai dengan tekanan tertinggi di lengan (Ababneh et al., 2020).

Upaya penanganan penyakit kaki diabetik dengan mengontrol glikemia. Normoglikemia akan menunda onset dan memperlambat perkembangan neuropati diabetik, retinopati dan nefropati. Strategi pencegahan penting untuk mengurangi risiko ulkus, gangrene dan amputasi dapat dilakukan dengan pendidikan kesehatan pada pasien terkait gaya hidup dan olah raga/senam dan penilaian sirkulasi perifer untuk penyakit vaskular perifer dan neuropati dengan mengukur nilai ABI (Braiki et al., 2020). Senam kaki merupakan latihan untuk penderita DM guna meningkatkan sirkulasi darah ke area ekstremitas bawah sebagai upaya mencegah neuropati. Manfaat lainnya dapat memperkuat muskulus femoralis, muskulus gracilis, dan muskulus fibularis longus, meningkatkan gerak sendi dan mencegah terjadinya deformitas. Indikasi senam kaki dapat diberikan kepada seluruh penderita DMT1 dan DMT2. Sebaiknya diberikan sejak pasien didiagnosa DM sebagai tindakan pencegahan dini. Senam kaki ini juga dikontraindikasi pada klien yang mengalami perubahan fungsi fisiologis seperti dispnea atau nyeri dada (Setiyorini et al., 2018). Berdasarkan hasil penelitian tentang pengaruh senam kaki terhadap neuropati perifer penderita diabetes mellitus menggunakan skor IpTT (Ipswich Touch Test) di wilayah kerja Puskesmas Metro Pusat didapatkan hasil bahwa senam kaki diabetes dapat memperbaiki sirkulasi darah kaki lancer dengan rata-rata skor Ipswich Touch Test (IpTT) pretest $2,43 \pm 1,076$ dan posttest $3,24 \pm 1,179$, dan selisih mean $0,810 \pm 0,602 ; p$-value 0,000 ( $p<0,05)$ (Yulendasari et al., 2020).

Berdasarkan survei awal pada bulan November 2020, jumlah penderita DM dari bulan Januari sampai dengan bulan November 2020 di UPTD Puskesmas Sidareja berjumlah 185 orang dari 10 desa di Kecamatan Sidareja. Desa Karanggedang merupakan desa di Kecamatan Sidareja dengan angka kejadian DM paling tinggi diantara 10 desa yang lain. Desa Karanggedang memiliki jumlah penderita DM 61 orang sasaran DM dengan hasil gula darah lebih dari $200 \mathrm{mg} / \mathrm{dl}$. Mitra kegiatan ini adalah kelompok peduli diabetes mellitus Desa Karanggedang Kecamatan Sidareja. Kelompok ini terdiri dari 61 penderita DMT2. Anggota telah aktif dalam kegiatan prolanis di UPTD Puskesmas Sidareja setiap bulannya. Sebagai inisiasi kegiatan, PKM ini akan memfokuskan pada 15 anggota kelompok yang memenuhi kriteria yaitu penderita DM tipe 2 yang mengalami nyeri neuropati dengan skala nyeri 4-6, tidak ada ulkus dan tidak mengalami kelemahan ekstermitas bawah.

\section{MASALAH}

Hasil wawancara dengan anggota kelompok ditemukan beberapa permasalahan mitra antara lain sebagai berikut:

a. Kurang menyadari gaya hidup bagi penderita DMT2

b. Kurang pengetahuan cara meningkatkan sirkulasi perifer di kaki dengan senam kaki diabetes 
c. Kurang pengetahuan cara mencegah penyakit kaki diabetik sehingga mengurangi komplikasi ulkus dan gangrene yang berakibat amputasi dan kematian.

Jarak antara lokasi dengan kampus Universitas Harapan Bangsa sekitar $60,2 \mathrm{~km}$ yang dapat ditempuh dengan kendaran bermotor sekitar 1 jam 47 menit.

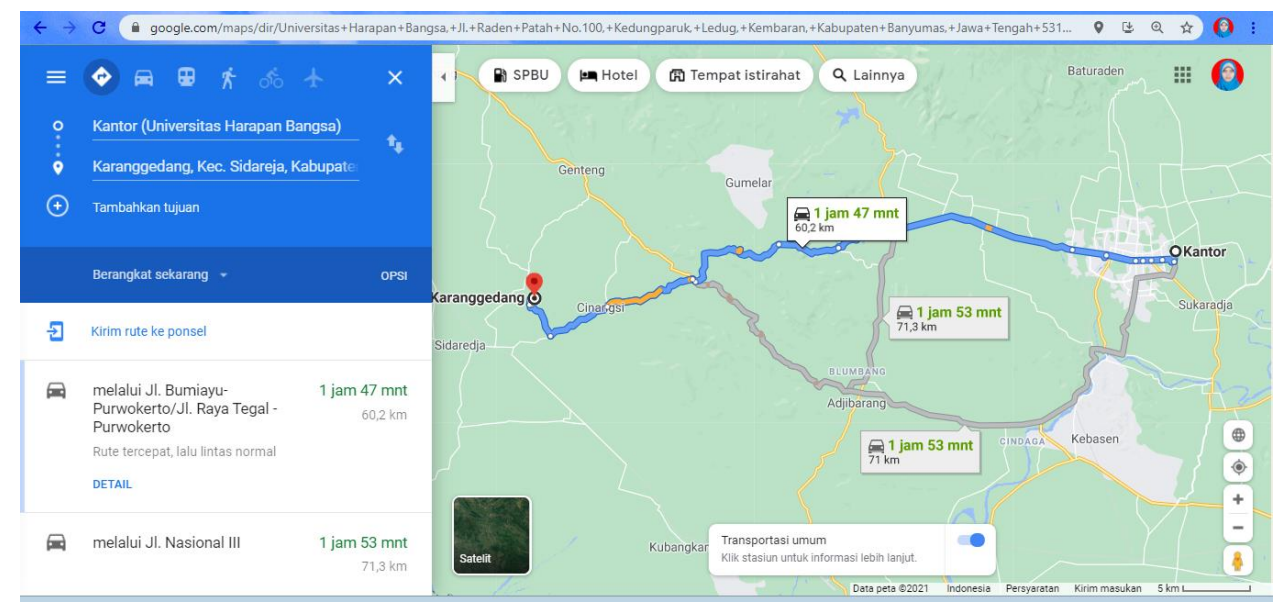

Gambar 1. Denah lokasi PKM

\section{METODE}

a. Persiapan

Tahap ini dimulai dengan penyusunan proposal kegiatan PKM, dilanjutkan dengan koordinasi dengan Kepala Desa, kader kesehatan Desa Karanggedang Kecamatan Sidareja. Menetapkan jadwal, rancangan kegiatan, teknis pelaksanaan serta mendata seluruh peserta yang memenuhi kriteria. Menyiapkan materi pelatihan, video pembelajaran senam kaki diabetes, sarana pendukung pada kegiatan ini antara lain leaflet, LCD, Laptop, Microphone, serta menyiapkan tenaga pelatih demonstrasi senam kaki diabetes.

b. Pelaksanaan

Implementasi kegiatan dilakukan pada 24 Mei - 5 Juli 2021 selama 14 kali pertemuan yaitu pertemuan ke-1 memberikan pendidikan kesehatan gaya hidup dan penatalaksanaan penyakit DM serta pencegahan penyakit kaki diabetik. Pertemuan ke-2 memberikan edukasi cara meningkatkan sirkulasi perifer di kaki dengan senam kaki diabetes. Pertemuan ke-3 hingga 14 adalah pelaksanaan senam kaki diabetes serial tiga kali dalam sepekan selama satu bulan yang dilaksanakan di Posyandu Lansia. Metode yang digunakan yaitu ceramah, diskusi, tanya jawab, wawancara tertutup, demonstrasi, redemonstrasi, dan menonton video senam kaki diabetes.

c. Monitoring

Tahap persiapan: sarana dan prasarana terpenuhi, video pembelajaran senam kaki diabetes tersedia dan mudah diakses melalui laman https://www.youtube.com/watch?v=3tvDbqh7b2o dan mendapatkan sertifikat Hak Kekayaan Intelektual (HKI) dari Kementerian Hukum Dan Ham Dirjen Kekayaan Intelektual RI dengan nomor pencatatan EC00202117117 pada 24 Maret 2021. Tenaga pelatih telah terampil 
melakukan senam kaki diabetes, jadwal pelaksanaan dan tempat dapat disepakati bersama. Tahap pelaksanaan: kegiatan serial senam kaki selama 1 bulan berjalan dengan baik, kegiatan terlaksana sesuai rencana kegiatan, seluruh peserta tertib dan antusias, diskusi berjalan lancar, pemateri dapat menjawab pertanyaan seputar diet hipertensi dengan baik, pemateri dapat mendemonstrasikan senam kaki diabetes dengan baik.

d. Evaluasi

Secara umum peserta edukasi tentang DM dan penatalaksanaan perawatan kaki diabetes dengan baik. Selama proses pelaksanaan edukasi terdapat beberapa hal yang berjalan di luar perencanaan, diantaranya yaitu sejumlah $20 \%$ peserta pelatihan adalah lansia sehingga daya tangkap terhadap meteri lebih lambat. Upaya yang dilakukan untuk mengatasi ini yaitu dengan memberikan edukasi dan pelatihan dengan tempo lambat, mengulang-ulang kembali informasi yang penting, mengevaluasi dengan pertanyaan, penggunaan bahasa yang sederhana dan mudah dimengerti. Pada tahap senam kaki secara serial seluruh peserta senam kaki diabetes mampu mempraktikkan dengan baik dan benar.

\section{HASIL DAN PEMBAHASAN}

Berikut merupakan karakteristik riwayat menderita hipertensi, lama menderita DM, skala nyeri pre dan post, dan keluhaan baal peserta kegiatan PKM.

Tabel 1. Karakteristik riwayat menderita hipertensi, lama menderita DM, skala nyeri pre dan post, dan keluhaan baal peserta kegiatan PKM

\begin{tabular}{lccc}
\hline Karakteristik & Frekuensi & Persentase & Persentase Kumulatif \\
\hline $\begin{array}{l}\text { Hipertensi } \\
-\quad \text { Tidak }\end{array}$ & 6 & 40,0 & 40,0 \\
$-\quad$ Ya & 9 & 60,0 & 100,0 \\
\hline Lama DM (tahun) & & & \\
$-\quad 1$ & 1 & 6,7 & 6,7 \\
-2 & 4 & 26,7 & 33,3 \\
-3 & 3 & 20,0 & 53,3 \\
-4 & 4 & 26,7 & 80,0 \\
-5 & 2 & 13,3 & 93,3 \\
$-\quad 6$ & 1 & 6,7 & 100,0 \\
\hline Nyeri Pekan 1 (Pre) & & & \\
-4 & 4 & 26,7 & 26,7 \\
$-\quad 5$ & 7 & 46,7 & 73,3 \\
$-\quad 6$ & 4 & 26,7 & 100,0 \\
\hline Nyeri Pekan 4 (Post) & & & \\
-2 & 4 & 26,7 & 26,7 \\
-3 & 8 & 53,3 & 80,0 \\
-4 & 3 & 20,0 & 100,0 \\
\hline
\end{tabular}




\begin{tabular}{lccc}
\hline Karakteristik & Frekuensi & Persentase & Persentase Kumulatif \\
\hline $\begin{array}{l}\text { Keluhan Baal Pekan } \\
1 \text { (Pre) }\end{array}$ & & & \\
$-\quad$ Tidak & 3 & 20,0 & 20,0 \\
$-\quad$ Ya & 12 & 80,0 & 100,0 \\
\hline Keluhan Baal Pekan & & & \\
4 (Post) & 10 & 66,7 & 66,7 \\
$-\quad$ Tidak & 5 & 33,3 & 100,0 \\
$-\quad$ Ya & & &
\end{tabular}

Berdasarkan tabel tersebut terlihat bahwa mayoritas peserta memiliki riwayat hipertensi sejumlah $9(60 \%)$ orang, lama menderita DM terlama 6 tahun, skala nyeri pre sebesar 5 (nyeri sedang) yang menurun 2 poin pada pengukuran post yaitu 3 (nyeri ringan), mengeluh baal pre sebanyak 12 (80\%) dan membaik menjadi $5(33,5)$ orang saja.

Tabel 2. Karakteristik umur, GDS, Skala Nyeri dan nilai ABI peserta kegiatan PKM

\begin{tabular}{lcccc}
\hline Karakteristik & Minimum & Maksimum & $\begin{array}{c}\text { Rata- } \\
\text { Rata }\end{array}$ & Std Deviasi \\
\hline Umur (tahun) & 45 & 65 & 55,27 & 6,39 \\
GDS Pre (mg/dl) & 174 & 350 & 216,07 & 40,73 \\
GDS Post (mg/dl) & 157 & 221 & 185,00 & 17,34 \\
$\begin{array}{l}\text { Skala Nyeri Pekan 1 } \\
\text { (Pre) }\end{array}$ & 4 & 6 & 5,00 & 0,76 \\
$\begin{array}{l}\text { Skala Nyeri Pekan 4 } \\
\text { (Post) }\end{array}$ & 2 & 4 & 2,93 & 0,70 \\
ABI Pekan 1 (Pre) & 0,72 & 0,88 & 0,81 & 0,05 \\
ABI Pekan 4 (Post) & 1,06 & 1,26 & 1,12 & 0,05 \\
\hline
\end{tabular}

$(n=15$, sumber primer $)$

Berdasarkan tabel tersebut terlihat bahwa peserta memiliki rata-rata umur 55,27 tahun, kadar GDS pre $216,07 \mathrm{mg} / \mathrm{dl}$ dan menurun saat post menjadi $185 \mathrm{mmg} / \mathrm{dl}$, skala nyeri pre 5 (sedang) dan menurun pada pengukuran post 2,93 (ringan), nilai $A B I$ pre seluruh peserta abnormal dengan rata-rata 0,81 dan membaik seluruhnya saat post dengan rata-rata 1,12 (normal). Data kadar GDS, skala nyeri dan nilai ABI dianalisa normalitasnya menggunakan uji Shapiro-Wilk didapatkan data normal untuk kadar GDS post $(p=0,860)$ dan nilai $A B I$ pre $(p=0,693)$. Data lainnya tidak normal karena memiliki nilai $p<0.05$ (rentang nilai $0,01-0,40$ ), maka untuk melihat perbedaan nilai pre dan post menggunakan uji nonparametrik Wilcoxon diperoleh hasil sebagai berikut: 
Tabel 3. Perbedaan kadar GDS, Skala Nyeri, Dan Nilai ABI Pre Dan Post

\begin{tabular}{llcc}
\hline \multicolumn{2}{c}{ Nilai } & Frekuensi & Nilai p \\
\hline GDS Post- GDS Pre & Menurun & 15 & $0,001^{*}$ \\
& Meningkat & 0 & \\
& Sama & 0 & $0,000^{*}$ \\
\hline Nyeri Pre - Nyeri & Menurun & 15 & \\
Post & Meningkat & 0 & $0,001^{*}$ \\
& Sama & 0 & \\
\hline ABI Post - ABI Pre & Menurun & 0 & \\
& Meningkat & 15 & \\
& Sama & 0 & \\
\hline
\end{tabular}

$\left({ }^{*}=\right.$ signifikan, uji nonparametrik Wilcoxon)

Berdasarkan tabel tersebut didapatkan hasil bahwa seluruh 15 (100\%) peserta menunjukkan perbaikan pada kadar GDS, skala nyeri, dan nilai $A B I$ setelah kegiatan PKM senam kaki diabetes selama 1 bulan dengan frekuensi 12 kali. Berikut merupakan foto dokumentasi pelaksanaan PKM:
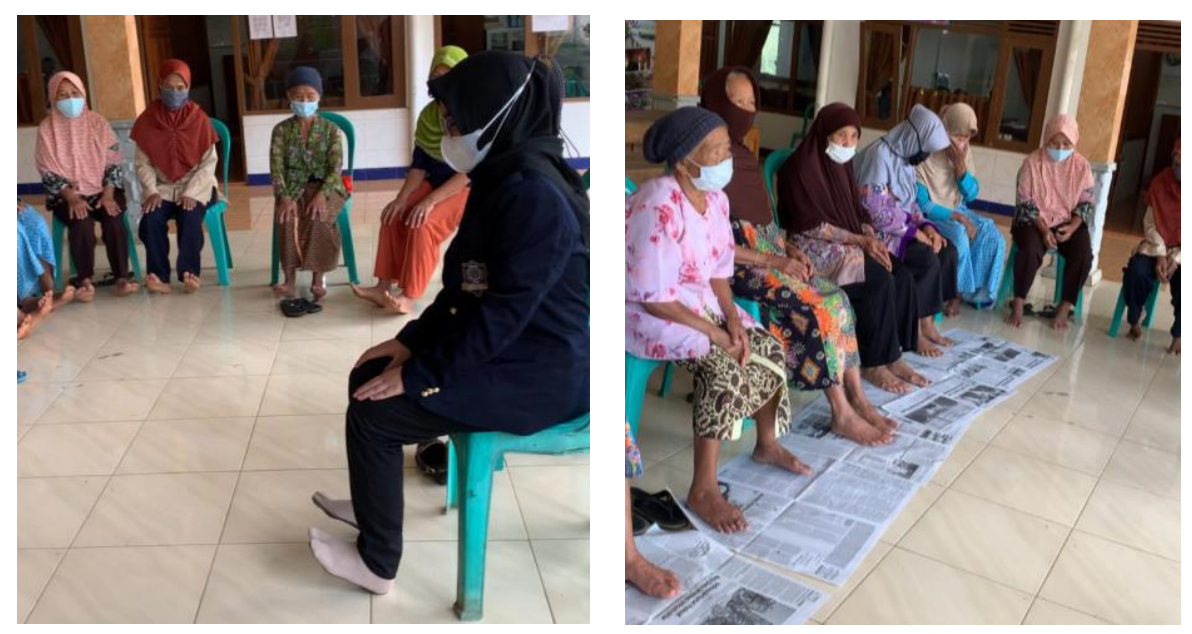

Gambar 2. Foto kegiatan PKM edukasi dan demonstrasi senam kaki diabetes

Diabetes melitus termasuk penyakit metabolik yang disebabkan karena gangguan pada kinerja dan atau jumlah insulin sehingga menyebabkan glukosa darah yang tinggi. Jumlah penderita tipe DMT2 mencapai 90-95\% dibandingkan tipe DM yang lainnya (Dietrich et al., 2017). Kondisi hiperglikemia pada penderita DM disebabkan karena abnormalitas pankreas yaitu penurunan sensitivitas dan jumlah sekresi insulin, peningkatan proses glukoneogenesis sehingga meningkatkan glukosa produk hati, adanya stimulasi glukagon dan katekolamin serta resistensi insulin di jaringan perifer yang yang mengganggu transportasi dan metabolisme glukosa. Diabetes mellitus menurunkan kapasitas fungsional individu dan kualitas hidup, menyebabkan morbiditas yang signifikan dan kematian dini (Gupta et al., 2020).

Hasil kegiatan PKM ini didapatkan bahwa mayoritas peserta memiliki riwayat hipertensi sejumlah $9(60 \%)$ orang, lama menderita DM terlama 6 
tahun, dan seluruh responden berjenis kelamin wanita, dan GDS pre 216,07 $\mathrm{mg} / \mathrm{dl}$ dan menurun saat post menjadi $185 \mathrm{mmg} / \mathrm{dl}$. Hal ini sejalan dengan hasil penelitian sebelumnya tentang hubungan tekanan darah dan kadar GDS pada penderita hipertensi yaitu mayoritas responden berjenis kelamin perempuan $58(69,9 \%)$, memiliki penyakit DM sebesar $64(77,1 \%)$ responden. Rerata glukosa darah sebesar 212,94 mg/dl termasuk kategori hiperglikemia. Rerata tekanan darah $125,42 \mathrm{mmHg} / 80,98 \mathrm{mmHg}$. Rerata tekanan darah tersebut termasuk kategori tekanan darah terkontrol. Serta terdapat hubungan yang bermakna $\left(\mathrm{p}_{\text {sistolik }} ; 0,026\right.$, dan $\left.\mathrm{p}_{\text {diastolik }} ; 0,032\right)$ dan sangat kuat antara kadar glukosa darah dan tekanan darah ( $r$ hitung sistolik; 0,815 dan $r$ hitung diastolik; 0,777). Berdasar penelitian tersebut dapat diambil kesimpulan bahwa kadar glukosa darah berhubungan erat dengan tekanan darah pada penderita hipertensi dan semakin tinggi kadar glukosa darah akan semakin meningkat tekanan darahnya (Novitasari \& Wirakhmi, 2020). Serta penelitian lainnya didapatkan bahwa rata-rata umur responden yaitu 64,20 tahun dengan jenis kelamin perempuan mendominasi yaitu sebanyak 19 (73,08\%) lansia dengan rata-rata tekanan darah lansia sebesar 172,31 / 94,04 mmHg. Rata-rata tekanan darah lansia tersebut termasuk kategori hipertensi derajat 2 . Berdasar penelitian tersebut memperkuat bahwa hipertensi menjadi semakin besar seiring bertambahnya usia (Novitasari \& Wirakhmi, 2018).

Hipertensi adalah penyakit yang ditandai dengan peningkatan tekanan darah sistolik dan diastolik di atas ukuran normal. Banyak faktor yang menyebabkan hipertensi seperti genetik dan lingkungan atau keduanya berperan secara bersamaan. Mekanisme tersebut akan mempengaruhi ion sodium, keseimbangan cairan dan vasomotor yang berperan dalam pengaturan tekanan darah. Faktor lingkungan seperti DM, obesitas, merokok, konsumsi alkohol, stres psikososial dan kurangnya olahraga dapat menyebabkan hipertensi. Patogenesis hipertensi pada penderita DMT2 sangat kompleks, banyak faktor berpengaruh pada peningkatan tekanan darah antara lain resistensi insulin, kadar gula darah plasma, obesitas, disfungsi sel, peradangan, stres oksidatif, disfungsi vaskular, retensi natrium, eksitasi simpatik, aktivasi sistem renin-angiotensin-aldosteron (RAAS), dan kerusakan ginjal (Ferrannini \& Cushman, 2012).

Berdasarkan hasil kegiatan PKM peserta memiliki rata-rata umur 55,27 tahun. Ini terkait dengan proses degenerasi yang dapat menyebabkan berbagai penyakit metabolik seperti DM. Penambahan usia akan menyebabkan penurunan fungsi organ-organ tubuh seperti penurunan aktivitas sel beta pancreas pada sistem endokrin, obesitas yang menyebabkan penumpukan lemak di jaringan visceral sehingga akan memicu resistensi insulin (Setiyorini et al., 2018). Hiperglikemia kronik menyebabkan disfungsi sel endotel yang berperan pada perkembangan penyakit berbagai penyakit seperti hipertensi dan PAD (Tabloski, 2014). Perkembangan hiperglikemia menyebabkan disfungsi endotel di dinding pembuluh darah melalui beberapa mekanisme, yaitu peningkatan produk protein yang terglikasi sehingga merubah tekanan intravaskular dan mengganggu fungsi serebrovaskular karena ketidakseimbangan NO dan prostaglandin, menurunnya produksi NO karena adanya peningkatan aktivasi PKC intraseluler, efek vasokonstriksi karena peningkatan produksi DAG, stres oksidatif karena meningkatnya lipoprotein teroksidasi, terutama LDL kolesterol kecil (LDL teroksidasi) yang bersifat aterogenik, serta peningkatan prothrombosis dan agregasi trombosit (Dietrich et al., 2017). Disfungsi endotel bermanifestasi pada proliferasi sel endotel, penebalan pada lapisan membran basal yang berkembang menjadi 
penyakit mikrovaskuler dan iskemia jaringan. Hiperglikemia juga dikaitkan dengan peningkatan tromboksan A2 yang menyebabkan hiperkoagulabilitas plasma (Braiki et al., 2020). Disfungsi sel endothel pembuluh darah tersebut menyebabkan gangguan sirkulasi darah, kerusakan saraf dan struktur lainnya di kaki. Kondisi awal neuropati ditandai dengan keluhan kesemutan, lemah, mati rasa, dan nyeri di kaki (Rachek, 2014).

Mikroangiopati dan makroangiopati sebagai komplikasi DM dapat menyebabkan penurunan kualitas hidup hingga kematian. Salah satu kerusakan makrovaskuler penderita DM seperti PAD pada tungkai atau kaki diabetes (Braiki et al., 2020) yang bila diiringi dengan infeksi dapat amputasi dan kecacatan (Dietrich et al., 2017). Peripheral artery disease adalah berbagai penyakit yang mempengaruhi arteri nonkardiak dan nonintrakranial yang disebabkan karena aterosklerosis, gangguan inflamasi pada dinding arteri (vaskulitis) dan arteriopati inflamasi, merokok, DM, peningkatan lipoprotein dan kadar homosistein, serta penyakit ginjal kronis. Usia meningkatkan prevalensi PAD, sedangkan gender tidak berberan banyak pada prevalensi PAD, tetapi pria lebih sering timbul gejala dibandingkan wanita yang lebih sering asimtomatik. Kondisi komorbiditas selama perjalanan 1 tahun PAD seperti penyakit jantung koroner pada 5,35\% pasien dan penyakit serebrovaskular (stroke iskemik) pada 4,52\% pasien, serta dalam 4 tahun PAD pasien mengalami gejala yang terus memburuk hingga amputasi pada $26 \%$ pasien. Apabila $\mathrm{ABI}$ kurang dari 0,9 berkontribusi dua kali lebih tinggi menyebabkan kematian (Kullo \& Rooke, 2016).

Beberapa tanda klasik dari PAD seperti ketidaknyamanan ketika melakukan aktivitas, ketidaknyamanan kaki yang atipikal keluhan nyeri iskemia di kaki, penurunan nadi per menit, bruit arteri, pengisian kapiler melambat, pucat ketika kaki posisi dielevasikan, dan perubahan masa otot. Apabila pasien mengalami iskemia pada kaki dapat menyebabkan ulserasi atau gangrene hingga berisiko amputasi. Maka nilai $A B I$ digunakan sebagai skrining agar PAD cepat terdeteksi. Sesuai rekomendasi AHA maka fokus skrining dilakukan pada populasi usia lebih dari 50 tahun, menderita DM dan memiliki riwayat kebiasaan merokok (AbuRahma et al., 2020; Kullo \& Rooke, 2016).

Ankle Brachial Index (ABI) merupakan metode sederhana untuk screening PAD dan untuk mengevaluasi prognosis kardiovaskular (CV) pada populasi umum (AlGhatrif et al., 2017). Nilai $A B I$ sering digunakan sebagai skrining noninvasif untuk mendeteksi PAD pada ekstremitas bawah. Pergelangan kaki dengan posisi anatomis lebih rendah umumnya memiliki tekanan pergelangan kaki yang sama atau lebih besar dari dibandingkan tekanan lengan ipsilateral. Rasio 1,0 atau lebih besar merupakan hal yang normal. Klasifikasi derajat $A B I$ yaitu $<0,89$ (abnormal); 0,91 hingga 0,99 (batas rendah); 1,0 hingga 1,3 (normal) dan $>1,3$ (adanya klafisikasi arteri) (AbuRahma et al., 2020). Nilai ABi selain digunakan sebagai prediktor PAD pada ekstremitas bawah, juga digunakan sebagai untuk menilai proses penyembuhan ulser, menentukan level amputasi, dan penyakit yang terkait kardiovaskuler (Trevethan, 2018).

American Diabetes Association merekomendasikan pengukuran $\mathrm{ABI}$ pada semua pasien DM yang berusia lebih dari 50 tahun. Pengukuran ABI dapat dilakukan pada posisi supine setelah beristirahat 5-10 menit. Pengukuran TD di pergelangan kaki dan lengan dilakukan secara bersamaan sebanyak 3 kali pengulangan. Manset spigmomanometer ditempatkan pada lengan dan pergelangan kaki pasien dan tekanan darah dicatat dalam tiga 
kali pengukuran. Nilai $A B I$ dihitung berdasarkan rata-rata pembacaan tiga kali. Manset spigmomanometer ditempatkan di sekitar pergelangan kaki di area arteri posterior tibialis. Manset spigmomanometer lainnya ditempatkan di lengan di area arteri brakialis (AlGhatrif et al., 2017). Tekanan yang lebih tinggi dari kedua pergelangan kaki dibagi oleh tekanan arteri brakialis. Pada subjek dengan sirkulasi arteri tungkai bawah normal, tekanan sistolik di pergelangan kaki biasanya $10-15 \mathrm{mmHg}$ lebih tinggi daripada dibandingkan lengan karena kecepatan gelombang nadi, menghasilkan $A B I>1,10$. Perhimpunan medis internasional besar merekomendasikan penghitungan $A B I$ dengan membagi tekanan tertinggi di tungkai dengan tekanan tertinggi di lengan (Ababneh et al., 2020).

Penyakit kaki penderita DM dapat berupa ulkus dengan komplikasi infeksi bakteri menyebabkan gangrene. Gangrene menyebabkan risiko amputasi yang tinggi pada penderita DM apabila tidak ditangani dengan baik (Braiki et al., 2020). Hasil pengukuran skala nyeri pre 5 (sedang) dan menurun pada pengukuran post 2,93 (ringan), nilai ABI pre seluruh peserta abnormal dengan rata-rata 0,81 dan membaik seluruhnya saat post dengan rata-rata 1,12 (normal). Senam kaki pada kegiatan PKM ini dilakukan selama 1 bulan sebanyak 12 serial. Melalui uji non parametric Wilcoxon didapatkan hasil bahwa seluruh 15 (100\%) peserta menunjukkan perbedaan yang signifikan pada kadar GDS, skala nyeri, dan nilai ABI.

Tujuan penatalaksanaan DM secara umum yaitu meningkatkan kualitas hidup penderita diabetes. Adapun tujuan penatalaksanaan jangka pendeknya yaitu menghilangkan keluhan DM, meningkatkan kualitas hidup dan mengurangi risiko komplikasi akut. Serta tujuan penatalaksanaan jangka panjangnya yaitu mencegah dan menghambat progresivitas mikroangiopati dan makroangiopati agar dapat menurunkan angka morbiditas dan mortalitas penderita DP. Upaya yang dilakukan berupa pengelolaan yang komprehensif pada pengendalian glukosa darah, tekanan darah, berat badan dan profil lipid (Eliana \& Yarsi, 2015).

Sebagai upaya meningkatkan kesadaran gaya hidup yang baik bagi penderita DMT2 pada kegiatan PKM pada tahap pertama dilakukan dengan pendidikan kesehatan tentang DM, mendampingi dan coaching sadar sebagai DM. Sesuai dengan pilar penatalaksaan DM, edukasi sebagai upaya promosi kesehatan yang memerlukan peran aktif penderita DM bersama tim kesehatan untuk mencapai perilaku hidup sehat. Materi yang perlu disampaikan meliputi konsep diabetes, tanda gejala, cara pengendalian dan pemantauan DM secara kontinyu, diet penderita DM / asupan makanan, aktifitas fisik dan pentingnya latihan jasmani, cara pemantauan glukosa darah dan urin secara mandiri, penangan hipoglikemia, pentingnya latihan jasmani secara teratur, cara perawatan kaki, penatalaksaan non farmakologis dan obat antihiperglikemia (Setiyorini et al., 2018).

Kegiatan tahap kedua pada PKM ini yaitu memberikan edukasi cara meningkatkan sirkulasi perifer di kaki dengan senam kaki diabetes. Hal ini sejalan dengan prinsip penatalaksaan DM. Edukasi perawatan kaki yang perlu diberikan pada penderita DM yaitu tentang anjuran menggunakan alas kaki yang datar dan lembut saat berjalan, melakukan pemeriksaan kaki secara rutin dan melaporkan pada petugas kesehatan apabila terdapat kulit yang mengelupas, kemerahan atau luka, menjaga kaki tetap bersih, tidak basah, mengeringkan sela - sela jari kaki, mengoleskan pelembab jika kulit kaki terasa kering, memotong kuku kaki secara teratur dan benar, menipiskan 
kalus bila ada, menggunakan kaos kaki berbahan katun (Setiyorini et al., 2018).

Upaya penanganan penyakit kaki diabetik dengan mengontrol kadar glukosa. Normoglikemia akan memperlambat perkembangan neuropati diabetik, retinopati dan nefropati. Strategi pencegahan penting untuk mengurangi risiko ulkus, gangrene dan amputasi dapat dilakukan dengan pendidikan kesehatan pada pasien terkait gaya hidup dan olah raga/senam dan penilaian sirkulasi perifer untuk penyakit vaskular perifer dan neuropati dengan mengukur nilai ABI (Braiki et al., 2020). Senam kaki merupakan latihan untuk penderita DM guna meningkatkan sirkulasi darah ke area ekstremitas bawah sebagai upaya mencegah neuropati. Manfaat lainnya dapat memperkuat muskulus femoralis, muskulus gracilis, dan muskulus fibularis longus, meningkatkan gerak sendi dan mencegah terjadinya deformitas. Indikasi senam kaki dapat diberikan kepada seluruh penderita DMT1 dan DMT2. Sebaiknya diberikan sejak pasien didiagnosa DM sebagai tindakan pencegahan dini. Senam kaki ini juga dikontraindikasi pada klien yang mengalami perubahan fungsi fisiologis seperti dispnea atau nyeri dada (Setiyorini et al., 2018). Senam kaki juga memperbaiki sirkulasi darah, memperkuat otot-otot kecil di kaki, meningkatkan kekuatan otot betis dan paha, mencegah kelainan bentuk kaki, dan meningkatkan gerak sendi (Setiyorini et al., 2018). Hal tersebut dilakukan pada tahap terakhir kegiatan PKM ini adalah senam kaki diabetes secara rutin 3 kali seminggu selama 1 bulan dan didapatkan hasil seluruh peserta meningkat nilai $A B I$ menjadi normal. Peserta PKM dapat mengakses video pembelajaran senam kaki diabetes melalui laman https://www.youtube.com/watch?v=3tvDbqh7b2o dari handphone. Video senam kaki telah mendapatkan sertifikat Hak Kekayaan Intelektual (HKI) dari Kementerian Hukum Dan HAM Dirjen Kekayaan Intelektual RI dengan nomor pencatatan EC00202117117 pada 24 Maret 2021.

\section{KESIMPULAN}

Kesadaran tentang gaya hidup yang baik pada penderita DMT2 dan pengetahuan cara meningkatkan sirkulasi perifer di kaki dengan senam kaki diabetes sehingga mengurangi komplikasi ulkus dan gangrene yang berakibat amputasi dan kematian pada penderita DMT2 di Desa Karanggedang meningkat.

\section{DAFTAR PUSTAKA}

Ababneh, M., Al Ayed, M. Y., Robert, A. A., \& Al Dawish, M. A. (2020). Clinical utility of the ankle-brachial index and toe brachial index in patients with diabetic foot ulcers. Current Diabetes Reviews, 16(3), 270-277.

AbuRahma, A. F., Adams, E., AbuRahma, J., Mata, L. A., Dean, L. S., Caron, C., \& Sloan, J. (2020). Critical analysis and limitations of resting anklebrachial index in the diagnosis of symptomatic peripheral arterial disease patients and the role of diabetes mellitus and chronic kidney disease. Journal of Vascular Surgery, 71(3), 937-945. https://doi.org/https://doi.org/10.1016/j.jvs.2019.05.050

AlGhatrif, M., Zane, A., Oberdier, M., Canepa, M., Studenski, S., Simonsick, E., \& Ferrucci, L. (2017). Lower mitochondrial energy production of the thigh 
muscles in patients with low-normal ankle-brachial index. Journal of the American Heart Association, 6(9), e00660.

Braiki, M., Khalifa, M. A., Faidi, B., Ghannouchi, M., \& Derbel, F. (2020). Introductory Chapter: Diabetic Foot. In The Eye and Foot in Diabetes. IntechOpen.

Dietrich, I., Braga, G. A., de Melo, F. G., \& da Costa Silva, A. C. C. (2017). The diabetic foot as a proxy for cardiovascular events and mortality review. Current Atherosclerosis Reports, 19(11), 1-5.

Eliana, F., \& Yarsi, B. P. D. F. (2015). Penatalaksanaan DM Sesuai Konsensus Perkeni 2015. PB. Perkeni.

Ferrannini, E., \& Cushman, W. C. (2012). Diabetes and hypertension: The bad companions. The Lancet, 380(9841), 601-610. https: //doi.org/10.1016/S0140-6736(12)60987-8

Gupta, G., Wadhwa, R., Pandey, P., Singh, S. K., Gulati, M., Sajita, S., \& Dua, K. (2020). Obesity and diabetes: pathophysiology of obesity-induced hyperglycemia and insulin resistance. In In Pathophysiology of obesityinduced health complications (pp. 81-97). Springer, Cham.

Kullo, I. J., \& Rooke, T. W. (2016). Peripheral artery disease. New England Journal of Medicine, 374(9), 861-871. https://doi.org/10.1056/NEJMcp1507631

Novitasari, D., \& Wirakhmi, I. N. (2018). Hubungan Nyeri Kepala Dengan Kemampuan Activity Of Daily Living Pada Penderita Hipertensi Di Kelurahan Mersi Purwokerto. Prosiding Seminar Nasional Hasil-Hasil Penelitian Dan Pengabdian Kepada Masyarakat: Enhancing Memory, Reproduction, And Quality Of Life In Eldery, 1(1).

http://lppm.uhb.ac.id/en/proceeding/proceeding-2018/hubungan-nyerikepala-dengan-kemampuan-activity-of-daily-living-pada-penderitahipertensi-di-kelurahan-mersi-purwokerto/

Novitasari, D. , \& Wirakhmi, I. N. (2020). The analysis of blood glucose level and blood pressure on hypertension patients in mersi village, East Purwokerto, Central Java. 1st International Conference on Community Health (ICCH), 20(1), 59-63. https://doi.org/https://doi.org/10.2991/ahsr.k.200204.014

Rachek, L. I. (2014). Glucose Homeostatis and the Pathogenesis of Diabetes Mellitus. In Progress in Molecular Biology and Translational Science. https: //doi.org/10.1016/B978-0-12-800101-1.00008-9

Setiyorini, E., Wulandari, N. A., Sari, Y. K., Sarwoko, E., Nurfarida, N. I., Ahsan, M., Indawati, N., \& Kusumawati, E. D. (2018). Perawatan Lansia dalam Persektif Budaya. Media Nusa Creative.

Tabloski, P. A. (2014). Gerontological nursing. Pearson Education, Inc.

Trevethan, R. (2018). Subjecting the ankle-brachial index to timely scrutiny: is it time to say goodbye to the ABI? Scand J Clin Lab Invest, 78, 94-101.

Yulendasari, R., Isnainy, U. C. A. S., \& Herlinda, H. (2020). Pengaruh Senam Kaki Terhadap Neuropati Perifer Penderita Diabetes Mellitus Menggunakan Skort Iptt (Ipswich Touch Test) Di Wilayah Kerja Metro Pusat. Malahayati Nursing Journal, 2(2), 344-353. 